\title{
Diamond-Blackfan anaemia in a girl with a de novo balanced reciprocal $\mathrm{X} ; 19$ translocation
}

Peter Gustavsson, Gunnar Skeppner, Bertil Johansson, Torsten Berg, Laurie Gordon, Anders Kreuger, Niklas Dahl

\begin{abstract}
A 7 year old girl is described with congenital hypoplastic anaemia (Diamond-Blackfan anaemia, DBA) and an apparently balanced reciprocal translocation, 46,XX,t(X;19)(p21;q13). The girl has associated features including short stature, unilateral kidney hypoplasia, and a branchial cyst. Fluorescent in situ hybridisation (FISH) studies with 19q specific cosmids showed that the chromosome 19 breakpoint is located between the RYR1 and the XRCC1 loci spanning a physical region of $5 \mathrm{Mb}$. There is no family history of DBA and the parents and two healthy sibs have normal karyotypes. This is the first report of a balanced translocation associated with DBA and we suggest that the distinct phenotype has resulted from a de novo disruption of a functional gene. DBA can be inherited as an autosomal trait and our observation may indicate a candidate gene for the disorder in the 19 q13 region.

$(\mathcal{F}$ Med Genet 1997;34:779-782)
\end{abstract}

Departments of

Clinical Genetics and

Paediatrics, University

Children's Hospital,

S-751 85 Uppsala,

Sweden

P Gustavsson

A Kreuger

N Dahl

Department of

Paediatrics, Örebro

Regional Hospital,

Sweden

G Skeppner

Department of

Paediatrics, Västerås

County Hospital,

Sweden

T Berg

Department of Clinical

Genetics, Lund

University Hospital,

Sweden

B Johansson

Lawrence Livermore National Laboratory, Livermore, CA, USA

L Gordon

Correspondence to:

Dr Dahl.

Received 26 November 1996 Revised version accepted for publication 27 March 1997
Keywords: Diamond-Blackfan anaemia; balanced X;19 translocation; fluorescence in situ hybridisation; chromosome band 19q13

Congenital hypoplastic anaemia or DiamondBlackfan anaemia (DBA, McKusick 205900) is a rare macrocytic anaemia of unknown aetiology and pathogenesis. It is characterised by subnormal erythropoiesis with absent erythroid precursors and reticulocytopenia. ${ }^{1-4}$ The differentiation and proliferation of granulocytes, macrophages, and megakaryocytes are usually normal. More than $90 \%$ of the patients are anaemic before the age of 1 year. The diagnostic criteria (European Working Group on DBA, personal communication) are diagnosis before the age of 2 years, low reticulocyte counts, and selective deficiency of red cell precursors in the bone marrow ( $<5 \%$ of nucleated cells). Additional features which are often observed include macrocytosis, raised fetal haemoglobin, and increased red cell adenosine deaminase (ADA). Sister chromatid breakage should be normal which excludes Fanconi anaemia. Familial cases support the diagnosis.

About $25 \%$ of patients with DBA present with associated congenital physical anomalies. ${ }^{5}$ The most common single feature is malformations of the thumb. ${ }^{2}$ Other frequent defects include atrial or ventricular septal defects, anomalies of the forearm, webbed neck, cleft lip and palate, urogenital anomalies, strabismus, cataract, and short stature..$^{2-7}$

The majority of cases are sporadic, with an equal sex ratio, but at least $10 \%$ have a positive family history for the disorder. Both autosomal dominant $\mathrm{t}^{8-12}$ and autosomal recessive inheritance have been reported. ${ }^{13}{ }^{14}$ In addition, studies of several families indicate dominant inheritance with reduced penetrance. ${ }^{15-18}$

The molecular basis for the disease is unknown but successful bone marrow transplantation of DBA patients has unambiguously shown that the functional defect(s) is related to a haematopoietic progenitor cell or its derivatives. ${ }^{19} 20$ Attempts have been made to find inhibitors of erythropoiesis and claims have been made both for and against the presence of $\mathrm{T}$ cell inhibitors in erythropoiesis. ${ }^{21-24}$ Several investigators have tried to clarify the effect of haematopoietic growth factors on erythroid progenitors from patients with DBA. However, the in vitro response to growth factors, such as erythropoietin (EPO), IL-3, IL-6, GM-CSF, stem cell factor, and EPA, has yielded conflicting results. ${ }^{25-28}$ Molecular analyses of candidate genes, such as the EPO receptor, have also been undertaken, but no mutations have been identified. ${ }^{29}$

We describe a girl with a de novo balanced $\mathrm{X} ; 19$ reciprocal translocation in whom the haematological and clinical features were consistent with DBA.

\section{Materials and methods}

Standard chromosome preparations were made from bone marrow aspirate and from PHA stimulated peripheral blood derived from the proband. The parents' chromosomes were analysed from blood only. Conventional cytogenetic analysis of $\mathrm{G}$ banded chromosomes was carried out on 500 band metaphases. Analysis of sister chromatid breakage was performed after the induction of mitomycin C. The chromosome 19 cosmids used (Lawrence Livermore National Laboratory) and their relative order from the centromere to the telomere is: $16848,10084,9476,8764,22135$, 16250 , and $15567 .^{3031}$

Fluorescent in situ hybridisation was done essentially as previously described. ${ }^{32}{ }^{33}$ Cosmid DNA was labelled with biotin-11-dUTP or digoxigenin-16-dUTP (Boehringer Mannheim), using nick translation. Labelled DNA (50 ng) was combined with sonicated herring sperm DNA and $5 \mu \mathrm{g}$ Cot-1 DNA (GIBCO BRL), ethanol precipitated, air dried, and then dissolved in a hybridisation buffer $(50 \%$ 
formamide, $2 \times$ SSC, $10 \%$ dextran sulphate, and $50 \mathrm{mmol} / 1$ phosphate buffer, $\mathrm{pH} \mathrm{7.0)}$. Probes were denatured at $70^{\circ} \mathrm{C}$ for 10 minutes, followed by preannealing with Cot-1 DNA for 30 minutes at $37^{\circ} \mathrm{C}$.

Chromosome preparations were denatured using $70 \%$ formamide $/ 2 \times \mathrm{SSC}$ at $70^{\circ} \mathrm{C}$. After two minutes denaturation, the slides were incubated in an ice cold ethanol series $(70 \%$, $85 \%$, and $99 \%$ ) and then air dried. Hybridisation was carried out at $37^{\circ} \mathrm{C}$ overnight in a moist chamber.

After hybridisation, the slides were washed three times for five minutes in $50 \%$ formamide $/ 1 \times \mathrm{SSC}$ at $42^{\circ} \mathrm{C}$ and two $0.5 \times \mathrm{SSC}$ washes at $60^{\circ} \mathrm{C}$. Detection of probe hybridisation was achieved by the application of a single layer of avidin-fluorescein isothiocyanate, FITC (Vector), or rhodamine labelled antidigoxigenin (Boehringer Mannheim) for $30 \mathrm{~min}$ utes. The slides were then washed in $2 \times$ SSC, $0.05 \%$ tween for 15 minutes and in an ethanol series.

Chromosomes were counterstained with $0.05 \mu \mathrm{g} / \mathrm{ml} \quad 4$,6-diamidino-2-phenylindole, DAPI (Serva), and mounted in antifade solution (Vectashield). The slides were analysed with a Zeiss Axiophot epifluorescence microscope with a filter set for visualisation of rhodamine, FITC, and DAPI fluorescence. Images were merged using a CCD camera (Photometrics) and the IPlab software (Vysis). Photographs were taken directly from the computer monitor using Kodak 100 Ektachrome colour film.

\section{Case report}

The patient was born at term after an uneventful pregnancy (birth weight $3400 \mathrm{~g}$ ) to unrelated parents. The parents and two older sibs are all healthy. At the age of 1 month, the proband developed fatigue, pallor, and dyspnoea. Examination showed anaemia with a haemoglobin concentration of $5.5 \mathrm{~g} / \mathrm{dl}$. The $\mathrm{MCV}$ and MCHC were within the normal ranges and reticulocyte counts were low or in the lower normal range $(0-0.5 \%)$. Leucocyte and thrombocyte counts were normal. A bone marrow aspirate showed a selective decrease in erythroid precursors and reduced erythropoiesis. The proportion of erythrocyte progenitors was $<5 \%$ of nucleated bone marrow cells whereas myelopoiesis and the megakaryopoiesis were found to be normal. The heart and skeleton were normal and the only associated malformations were a branchial cyst on the right side and hypoplasia of the left kidney. Treatment with methylprednisolone has not resulted in an increase in $\mathrm{Hb}$ concentration and from the age of 6 weeks she has been dependent on blood transfusions. Her mean haemoglobin concentration at the age of 7 is approximately $7.0 \mathrm{~g} / \mathrm{dl}$, of which $5 \%$ represents fetal haemoglobin. At the age of 7 she is $106 \mathrm{~cm}$ tall (-3 SD) and her weight is $31.5 \mathrm{~kg}(+2.5 \mathrm{SD})$ (fig 1).

\section{Cytogenetic and FISH results}

Conventional cytogenetic studies showed an apparently balanced reciprocal translocation between the long arm of chromosome 19 and the short arm of the $\mathrm{X}$ chromosome, with the resulting karyotype $46, X, t(X ; 19)(p 21 ; q 13)$ (fig 2). The karyotypes of the parents and sibs are normal. FISH analyses showed that cosmid LLNL9476 was present on the $\operatorname{der}(19)$, whereas the LLNL8764 cosmid was located on the $\operatorname{der}(\mathrm{X})$ (fig 3). The cosmid LLNL9476 contains the RYR1 gene and the LLNL8764 cosmid contains the XRCC1 gene. ${ }^{31}$ The two cosmids/genes are separated by $5 \mathrm{Mb}$. The in situ hybridisation results can be summarised as $\bar{C}$ $46, \mathrm{X}, \mathrm{t}(\mathrm{X} ; 19)(\mathrm{p} 21 ; \mathrm{q} 13)$.ish $\mathrm{t}(\mathrm{X} ; 19)(9476$; 음 $8764+)$. The frequency of sister chromatid breakage was found to be normal $(<3 \%)$ which $\stackrel{\mathbb{D}}{\circ}$ excluded Fanconi anaemia.

\section{Discussion}

The introduction of molecular cytogenetic techniques has led to the identification of a number of submicroscopic translocations and deletions associated with clinically defined $\stackrel{\omega}{\mp}$ phenotypes. ${ }^{34}$ In such cases, it is assumed that the chromosome breakage occurs within, and $c$ disrupts, a functional gene. In our case, a de novo balanced reciprocal $\mathrm{X} ; 19$ translocation showed a distinctive haematopathology and $\vec{c}$ associated anomalies consistent with DBA. This is the first balanced translocation reported in a case of DBA. Two previous cases with DBA and cytogenetic aberrations, both affecting chromosome 1, have been reported. One patient showed an achromatic region in $\rightarrow$ chromosome $1 \mathrm{p} .{ }^{35}$ The second had a pericentric inversion of chromosome $1 . .^{36}$ The association between chromosome 1 aberrations and DBA remains unclear and has not, as yet, been

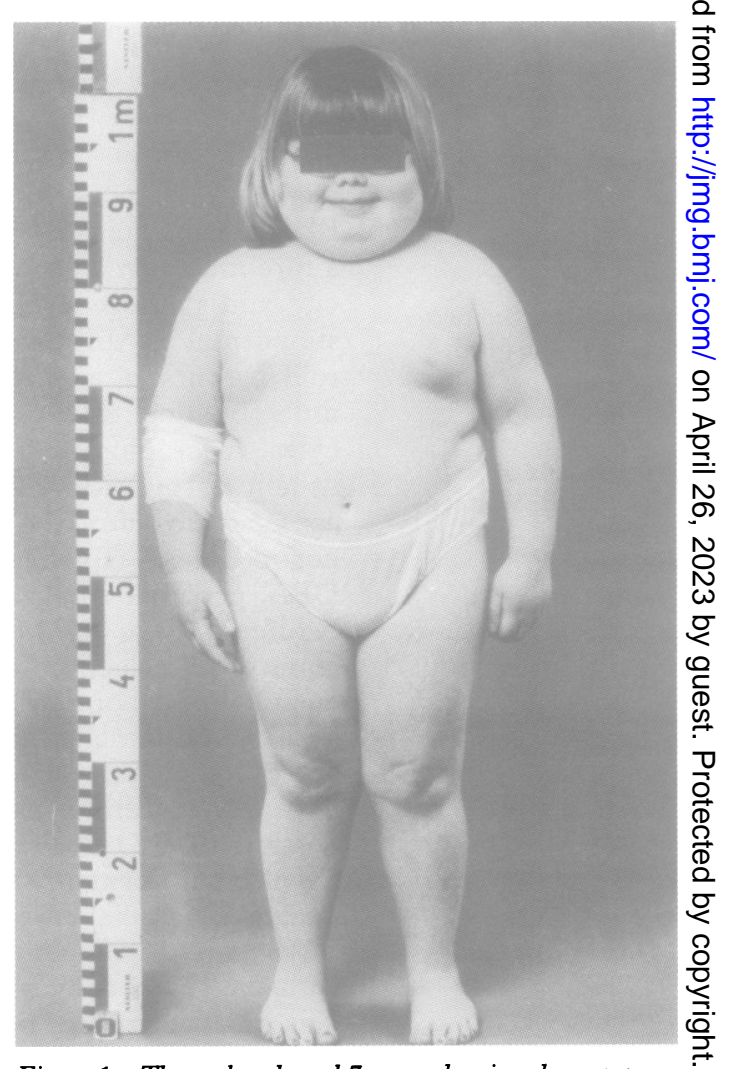

Figure 1 The proband aged 7 years showing short stature (-3 SD) and a Cushingoid habitus owing to steroid treatment. (Photograph reproduced with permission.) 

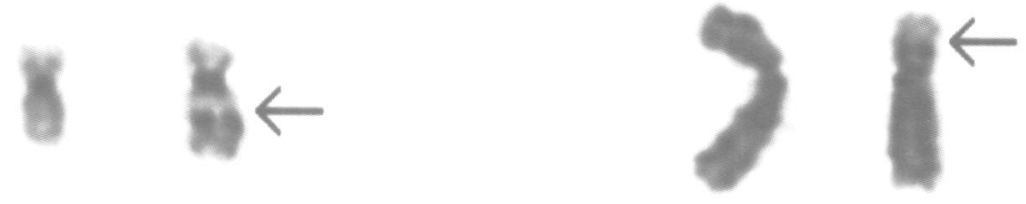

\section{9 der (19)}

$d e r(x)$

Figure 2 Partial karyotype of $G$ banded chromosomes showing the normal and derived chromosomes $X$ and 19. The normal 19 and the der (19)(19pter-19q13::Xp21-Xpter) are on the left and the normal $X$ and the $\operatorname{der}(X)(X q t e r-p 21:: 19 q 13-19 q$ ter $)$ are on the right.

substantiated by other methods, such as linkage analysis on families segregating for DBA.

There are no previous reports of constitutional monosomy for the $19 \mathrm{q} 13$ region corresponding to the site of the translocation breakpoint reported here. One report described a balanced $6 \mathrm{p} ; 19 \mathrm{q}$ translocation in a patient presenting at necropsy with bilateral multicystic dysplasia and clinodactyly. ${ }^{37}$ In our case left sided renal dysplasia was present and various anomalies of the hand and fingers are also an associated finding in DBA. Several acquired $19 q$ rearrangements have been reported in malignancy. ${ }^{38}$ Translocations involving $19 q$ have been described in chronic $B$ cell lymphoproliferative disorders ${ }^{39}$ and a putative glioma suppressor gene has been mapped to the $19 \mathrm{q}$ region between APOC2 and HRC. ${ }^{40}{ }^{41}$ An increased incidence of leukaemias but not gliomas or other solid tumours ${ }^{7}$ has been reported in cases with DBA.

In this report, we suggest that the DBA phenotype in the female patient is caused by disruption of the chromatin domain that causes loss of function of an otherwise normal gene. In approximately $10-20 \%$ of cases with DiamondBlackfan anaemia, the inheritance is autosomal and apparently monogenic. The sex ratio for the disorder is $1: 1$ and no families have been described with an $\mathrm{X}$ linked pattern of inherit-

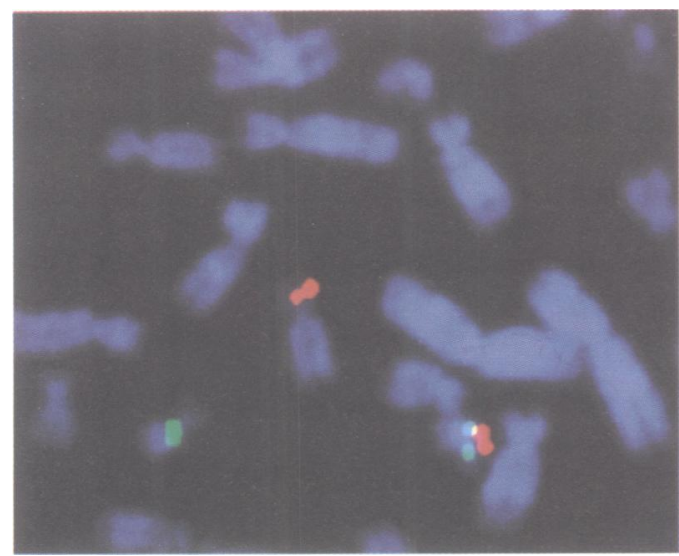

Figure 3 Fluorescent in situ hybridisation with the chromosome $19 q$ specific cosmids 9476 and 8764 (Lawrence Livermore National Laboratory). The two cosmids are separated by $5 \mathrm{Mb}$ which spans the breakpoint. The centromeric cosmid 9476 signal (green) was detected on the chromosome Xpter-p21:19q13-pter derivative and on the normal chromosome $19 q$. The more telomeric cosmid 8764 (red) shows a signal on the chromosome Xqter-p21:19q13-qter derivative and on the normal chromosome 19q. The yellow signal is the result of interference of the red and green signals on the normal chromosome 19. ance. In the absence of an $\mathrm{X}$ chromosome linked form of the disorder, our case may be the result of functional haploinsufficiency for a gene at $19 \mathrm{q} 13$. This is based on the assumption that the mutation can act in a dominant way, which has been shown previously. ${ }^{8-12}$ The complex clinical and genetic pattern in DBA has hampered the identification of the basic defect(s) underlying this disease and there has been speculation about genetic heterogeneity in the disorder. ${ }^{25}$ Although DBA may be caused by several genes, our observation may indicate one candidate locus for the disease.

The cosmids used for FISH analysis restrict the chromosomal breakpoint to a $5 \mathrm{Mb}$ interval, which has recently been mapped in detail. ${ }^{31}$ At least 14 genes are already assigned to the region. Defective erythroid progenitor cell maturation has been suggested as the origin of DBA. One candidate gene in the region is the transforming growth factor beta (TGFB1) gene, known to control proliferation and differentiation in many cell types. ${ }^{42}$ The region also contains three gene families with tandemly repeated and related genes. One family is the carcinoembryonic antigen (CEA) gene cluster which includes the subfamily encoding pregnancy specific beta-1glycoprotein (PSG). The PSG genes are highly expressed in the placenta which argues for their importance during development. ${ }^{43}$

Further FISH analyses with additional chromosome 19 derived cosmids will enable detailed mapping of the breakpoint and may precisely indicate candidate genes. Meanwhile, linkage analysis with polymorphic $19 \mathrm{q}$ markers in families segregating for DBA is in progress and will clarify the significance of the DBA candidate region.

\section{Note added in proof}

Since submission of this manuscript, we have performed linkage analysis in familial cases with DBA. The results show a significant two point lod score $(Z=7.08)$ and our combined findings confirm a locus for DBA on chromosome $19 \mathrm{q} 13$.

We wish to thank Professor Lore Zech for experienced advice and the European DBA Consortium and, its founder, the late Dr Lars Wranne. This study was supported by grants from the Children's Cancer Foundation of Sweden, the Swedish Medical Research Council, Harald Jeansson's Foundation, the Torsten and Ragnar Söderberg's Foundation, and the Markus Borgand Ragnar Soderberg's Foundation, and the Markus Borgstrom Foundation. Work at the LLNL was performed under the auspices of the US

1 Diamond LK, Blackfan KD. Hypoplastic anemia. Am $\mathcal{F}$ Dis Child 1938;56:464-7.

2 Alter BP. Childhood red cell aplasia. Am $\mathcal{F}$ Pediatr Hematol Oncol 1980;2:121-39.

3 Halperin DS, Freedman MH. Diamond-Blackfan anemia: etiology, pathophysiology, and treatment. Am $\mathcal{f}$ Pediatr Hematol Oncol 1989;1:380-94.

4 Young NS, Alter BP. Aplastic anemia: acquired and inherited. Philadelphia: Saunders, 1994.

5 Diamond LK, Wang WC, Alter BP. Congenital hypoplastic anemia. Adv Pediatr 1976;22:349-78.

6 Ball SE, McGuckin CP, Jenkins G, et al. Diamond-Blackfan anaemia in the UK: analysis of 80 cases from a 20 -yea birth cohort. $B r \mathcal{F}$ Haematol 1996;94:645-53.

7 Janov AJ, Leong T, Nathan D, et al. Diamond Blackfan anemia. Natural history and sequelae of treatment. Medicine (Baltimore) 1996;75:77-87.

8 Lawton JWM, Aldrich JE, Turner TL. Congenital erythroid hypoplastic anaemia: autosomal dominant transmission. Scand $f$ Haematol 1974;13:276-80.

9 Gray PH. Pure red-cell aplasia. Med f Aust 1982;1:519-21. 
10 Viskochil DH, Carey JC, Glader BE, et al. Congenital hypoplastic (Diamond-Blackfan) anemia in seven members of one kindred. Am $₹$ Med Genet 1990;35:251-6.

11 Hurst JA, Baraitser M, Wonke B. Autosomal dominant transmission of congenital erythroid hypoplastic anemia transmission of congenital erythroid hypoplastic anemia

12 Gojic V, van't Veer-Korthof ET, Bosch LJ, et al. Congenital hypoplastic anemia: another example of autosomal dominant transmission. Am $\mathcal{F}$ Med Genet 1994;50:87-9.

13 Estren S, Dameshek W. Familial hypoplastic anemia of childhood. Am $₹$ Dis Child 1947;73:671-87.

14 Madanat F, Arnaout M, Hasan A, et al. Red cell aplasia resembling Diamond-Blackfan anemia in seven children in a family. Am $\mathcal{F}$ Pediatr Hematol Oncol 1994;16:260-5.

15 Förare SA. Pure red cell anaemia in step siblings. Acta Paediatrica 1963;52:159-60.

16 Mott MG, Apley J, Raper AB. Congenital (erythroid) hypoplastic anaemia: modified expression in males. Arch Dis Child 1969;44:757-60.

17 Hunter RE, Hakami N. The occurrence of congenital hypoplastic anemia in half brothers. $\mathcal{F}$ Pediatr 1972;81:346-8.

18 Altman AC, Gross S. Severe congenital hypoplastic anemia. Transmission from a healthy female to opposite sex Transmission from a healthy female to opposite sex

19 Iriondo C, Garijo J, Baro J. Complete recovery of hemopoiesis following bone marrow transplant in a patient with esis following bone marrow transplant in a patient with
unresponsive congenital hypoplastic anemia. Blood 1984;6: unrespo

20 Greinix HT, Storb R, Sanders JE, et al. Long-term survival and cure after marrow transplantation for congenital hypoplastic anaemia (Diamond-Blackfan syndrome). $\mathrm{Br} \mathcal{F} \mathrm{Hae}$ matol 1993;84:515-20.

21 Hoffman R, Zanjani ED, Vila J, et al. Diamond-Blackfan syndrome: lymphocyte-mediated suppression of erythropoiesis. Science 1976;193:899-900.

22 Freedman MH, Saunders EF. Diamond-Blackfan syndrome: evidence against cell-mediated erythropietic suppression. Blood 1978;51:1125-8.

23 Nathan DG, Clarke BJ, Hillman DG, et al. Erythroid precursors in congenital hypoplastic (Diamond-Blackfan) precursors in congenital hypoplastic

24 Sawada K, Koyoagawa Y, Sakaruma S, et al. DiamondBlackfan syndrome: a possible role of cellular factors for Blackfan syndrome: a possible role of cellular factors for 65.

25 Dunbar CE, Smith DA, Kimball J, et al. Treatment of Diamond-Blackfan anaemia with haematopoietic growth factors, granulocyte-macrophage colony stimulating facto and interleukin 3: sustained remissions following IL-3. Br Haematol 1991;9:316-21.

26 Olivieri NF, Grunberger T, Ben-David Y, et al. DiamondBlackfan anemia: heterogenous response of hematopoietic progenitor cells in vitro to the protein product of the Stee locus. Blood 1991;78:2211-15.

27 Sieff CA, Yokoyama CT, Zsebo KM, et al. The production of Steel factor mRNA in Diamond-Blackfan anaemia: long-term cultures and interactions of Steel factor with erythropoietin and interleukin-3. Br f Haematol 1992;82: 640-7.
28 Gillio AP, Faulkner L, Altner BP, et al. Treatment of Diamond-Blackfan anemia with recombinant human IL-3. Blood 1993;82:744-51.

29 Dianzani I, Garelli E, Dompe C, et al. Mutations in the erythropoietin receptor gene are not a common cause of Diamond-Blackfan anemia. Blood 1996;87:2568-72.

30 Gordon L, Bergmann A, Christensen M, et al. A 30-Mb metric fluorescence in situ hybridization map of human chromosome 19q. Genomics 1995;30:187-92.

31 Ashworth LK, Batzer MA, Brandriff B, et al. An integrated metric physical map of human chromosome 19. Nat Genet 1995;1:422-7.

32 Pinkel D, Straume T, Gray JW, et al. Cytogenetic analysis $\stackrel{\mathbb{D}}{-}$ using quantitative, high-sensitivity, fluorescence in situ hybridization. Proc Natl Acad Sci USA 1986;83:2934-8.

33 Lichter $\mathrm{P}$, Cremer $\mathrm{T}$, Borden J, et al. Delineation of individual human chromosomes in metaphase and interphase cells by in situ suppression hybridization using recombinant DNA libraries. Hum Genet 1988;80:224-34.

34 Tommerup N. Mendelian cytogenetics. Chromosome rear- $\bar{\nabla}$ rangements associated with mendelian disorders. $f$ Med Genet 1993;30:713-27.

35 Tartaglia AT, Propp S, Amarose AP, et al. Chromosome abnormality and hypocalcemia in congenital erythroid $\vec{\circ}$ hypoplasia (Blackfan-Diamond syndrome). Am 7 Med 1966;41:990-9.

36 Heyn $R$, Kurchynski $E$, Schmickel $R$. The association of Blackfan-Diamond syndrome, physical abnormalities, and an abnormality of chromosome $1 . \mathcal{F}$ Pediatr 1974;85:531-3.

37 Groenen PMA, Garcia E, Thoelen R, et al. Isolation of cos- $\dot{\omega}$ mids corresponding to the chromosome breakpoints of a de $\perp$ novo autosomal translocation, $t(6 ; 19)(p 21 ; q 13.1)$, in a patient with multicystic renal dysplasia. Cytogenet Cell Genet 1996;75:210-15.

38 Heim S, Mitelman F, eds. Cancer cytogenetics. 2nd ed. New York: Wiley-Liss, 1995.

39 Crossen PE, Kennedy MA, Heaton DC, et al. Cloning and sequencing of a $t(14 ; 19)$ breakpoint that involves the $\mathrm{C} \mathrm{mu} C$ switch region. Genes Chrom Cancer 1993;8:60-2.

40 Yong WH, Ueki K, Chou D, et al. Cloning of a highly conserved human protein serine-threonine phosphatase gene from the glioma candidate region on chromosome 19q13.3. Genomics 1995;29:533-6.

41 Chou D, Miyashita T, Mohrenweiser HW, et al. The BAX gene maps to the glioma candidate region at $19 \mathrm{q} 13.3$, but is not altered in human gliomas. Cancer Genet Cytogenet 1996;88:136-40.

42 Border WA, Noble NA. Fibrosis linked to TGF-beta in yet another disease. 7 Clin Invest 1995;96:655-6.

43 Teglund S, Olsen A, Khan WN, et al. The pregnancyspecific glycoprotein (PSG) gene cluster on human chromosome 19: fine structure of the 11 PSG genes and identification of 6 new genes forming a third subgroup $(1)$ within the carcinoembryonic antigen (CEA) family. Genomics 1994;23:669-84. 